\title{
Development of Powerpoint-Based Learning Media on Learning Aqeedah Morals
}

\author{
Lufita Sari Sitorus ${ }^{1}$, Mardianto ${ }^{2}$, Hasan Matsum ${ }^{3}$ \\ 1,2,3 Islamic Education of Universitas Islam Negeri Sumatera Utara, Medan, Indonesia \\ lufitasari@gmail.com
}

\begin{abstract}
The purpose of this study was to find out: (1) Development of power point-based learning media on Aqeedah Moral learning in MTs N Kisaran, (2) The feasibility of power point-based learning media on learning Aqidah Akhlak in MTsN Kisaran, (3) Practicality of learning-based media power point on the learning of Aqeedah Morals in MTs $N$ Range, and (4) effectiveness of learning media based on power point on the learning of Aqeedah Morals in MTsN Kisaran in improving student learning outcomes. Research methods used by research and development methods $(R \& D)$. Product development procedures are carried out in stages: (1) potential and problems, (2) data collection, (3) product design, (4) validation, (5) product trials and (6) product revisions. The research findings show: (1) the development of power point-based learning media on Aqeedah Akhlak learning is done first by analyzing the needs and then proceed with the design of powerpoint media. The product produced as a learning medium that is used to facilitate students to learn, (2) the feasibility of power point-based learning media on Aqeedah Moral learning is done by material experts with a score of 83.33, a very valid category and a media expert with a score of 75.00 categories valid, so the cumulative score is 79.16 with a valid category, (3) practicality of power point-based learning media on Aqeedah Akhlak is done by conducting individual trials with a score of 80.83 very practical categories, small group trials with a score of 79.38 practical categories, and field group trials with a score of 89.75 very practical categories, so that when accumulated a score of 83.33 is obtained with a very practical category, and (4) the effectiveness of powerpoint-based learning media on Aqidah Moral learning in improving student learning outcomes obtained $N$ scores -Gain 0.51 with the effective category so that it can be concluded that the powerpoint development product for learning the Morals is effective for enhancing student achievement.
\end{abstract}

Keywords

reflection; reflective practice; professional development;

\section{Introduction}

Learning management strategies are very important in the overall learning strategy system. However the planning of the organizing strategy and the learning delivery strategy are good, but if the management strategy is not considered, the effectiveness of learning. Application of learning strategies to a teacher who will be able to successfully implement these strategies in the implementation of learning in class. The success of a teacher implementing a learning strategy is very dependent on the teacher's ability to analyze the existing learning conditions, such as learning objectives, student characteristics, learning resource constraints, and characteristics of the field of study. The results of the analysis of the learning conditions can be used as a basic foothold in determining learning strategies. 
Media and technology function as intermediaries between resource persons and learners, resource persons - writers, academics, and researchers - pour their knowledge and knowledge into a form of media that can be learned by Monday. As for media users students, readers, and users of library services - utilize media to obtain information and knowledge needed. A variety of media can be used for learning purposes in gaining knowledge of skills and attitudes and can be needed to carry out the learning process.

In general, media users for communicating knowledge and information will provide several benefits to their users, namely the delivery of message content and knowledge to be standard, the learning process clearer and more interesting, the learning process takes place more interactively, the user of time and energy in obtaining information and knowledge becomes more relaxed. Efficient Improve the quality of the learning process. The learning process becomes more flexible. Increases a positive attitude towards the content or learning material.

The use of image elements and sound elements in an integrated manner will be able to increase the user's understanding of the contents of the material contained in a media. In addition, the picture, sound and motion guide elements will make the information and knowledge contained in the media more interesting and relistic to be studied.

The function of learning media in a learning process include: first; be a guideline for students, so that the learning activities they do are directed and refer to the educational goals to be achieved including the basic competencies that have been set. Second; a guide for teachers or educators so they can also provide targeted and relevant teaching with educational goals. And third; learning media serves as an attraction for students to learn so that they are not bored or bored young.

Variety in learning media there are powerpoint based media namely power point is a computer program for presentations developed by Microsoft and displayed to the screen using the help of LCD projectors Power point is one program specifically designed to be able to display multimedia programs attractively, easily in making, easy to use, and relatively inexpensive because it does not require raw materials other than tools for data storage.

In increasing interesting learning and loading students, it is easy to understand the transfer of knowledge between educators and students. Teachers should be able to create learning media, one of which is based on powerpoints that are in accordance with the needs and desires of their students. In designing and developing percentage activities using the PowerPoint program application, you as a presenter can use text, image, and video elements. Views of information and knowledge on the media that are communicated through PowerPoint applications can contain text, image, and video elements. PowerPoint program as a media that is projected onto the screen, allows presenters to take advantage of the advantages of text, image and video downloads as an effective message communication suggestion.

The use of media and technology and media by the teacher is additional support during teacher-centered teaching, for example a teacher might use an electronic whiteboard to display it as a bar graph when students estimate population growth over time. The teacher also uses diagrams to show the meaning of a sentence. The use of technology and media by their students can utilize technology and media in a series of ways to enhance learning, a guide to achieving certain goals. Utilizing student-centered activities, the teacher uses their time to examine and correct student problems, consult with the rest individually and teach one by one in small groups.

In fact what happens now is that not many teachers are accustomed to using powerpoint based learning in the learning process. Tend to be more tight-faced or focus on textbooks, 
even though textbooks are not bad, it's just that we as teachers should make a variety of learning methods so that the learning we convey can be transcribed by students whose results will make student achievement increase for subjects he taught, including the teacher of aqeedah morals namely aqeedah morals. This can be known by researchers for example from direct observation and question and answer to the moral aqidah teachers in Asahan Regency. In my observations with the teacher aqidah morals, the teacher acknowledged that rarely even never held learning through powerpoint-based learning media. The teacher only uses books in school and sometimes the teacher displays pictures and posters to complete learning tools, even though facilities and infrastructure in the teaching place have been facilitated.

Learning media can be made in the form of text images, audio, and video depending on what learning is in accordance with the media that will be done. That way the children feel not bored in their learning will be orderly to see the picture on the projector. And make learning conducive. The media in which there is colorful writing and interesting text makes students not bored with learning.

To that end, researchers want to do a deeper study of media learning based on powerpoint and can make a product or display powerpoint on moral aqeedah subjects for the Madrasah Tsanawiyah level where the media will be based on powerpoint in the hope that students will be interested in seeing the appearance and interest in the powerpoint display later makes it easy for students to understand and find the learning interesting and fun. Madrasah Tsanawiyah became the level that the researchers chose because the researchers initially were curious about the complete school facilities and wanted to see the extent to which the facilities were complete with the learning process and a researcher of one of the school's admirers.

\section{Review of Literature}

Every human being has Aqeedah both in the form of monotheism, polytheism or other ideologies that lead to a solid and unwavering belief, follow Allah's commands and stay away from all its prohibitions and follow our leader namely the lover of Allah SWT the prophet Muhammad SAW.

According to Yunahar Ilyas (2003: 2) Etymologically Moral (Arabic) is a plural form of khuluq which means character, temperament, behavior or character. Morals are not only the rules or norms of behavior that govern the relationships between fellow human beings, but also the norms that govern human relations with God, even with the universe. Therefore morality is a trait that is embedded in the human soul, so that he will appear spontaneously if necessary, without requiring thought and consideration first.

Education is a very interesting world to be discussed and studied. Various problems are popping up more and more. It cannot be separated with the growing development of human thought in seeing the phenomena that occur and human awareness of the importance of education. Various changes that are always developing make humans are required to actively solve problems that occur (Lubis, 2019). Harahap (2019) states development is a process of developing a product and validating the effectiveness and efficiency of the product to be produced.

According to Sadiman Arief, et al. (1990-6) in the book Educational Platform that Educational Media or Learning Media is an intermediary or introduction to the message from the sender to the recipient of the message. The function and role of the media as visual aids in learning activities, namely as a means that can provide learning experiences, that can provide experiences to students to encourage student motivation in learning to clarify and facilitate abstract concepts and enhance the absorption of learning. 
According to Benny A. Pribadi, (2017: 18) In creating active and innovative learning a teacher (a messenger) must have full knowledge in accordance with their respective fields, so that the learning process runs well when giving to students (message recipients) all the tools used by a teacher are sound, writing, visual and audio visual media. Depends on how a teacher explains it. Media is a facilities that should be utilized maximally due to develop the student's motivation in learning. Learning tools basicallydefined as all tools that have a function to help the teacher to deliver learning material to the students in order to achieve the learning goal (Dewi, 2019).

The types of educational media by experts identify the main characteristics of the media into three main elements, namely: sound, visual, and motion. Visual form itself can be divided into three, namely: visual images, lines, and verb symbols. Multimedia Is a product of advances in digital technology. This media is able to provide a rich learning experience for its users. Multimedia can display messages and knowledge in the form of a combination or combination of several display formats, such as: text, audio, graphics, video, and animation simultaneously. With this ability, multimedia programs can display information and knowledge in a comprehensive manner that can be learned by students. The use of multimedia programs as learning suggestions can be tailored to the needs and learning abilities possessed by individual users. Nowadays multimedia learning users have integrated their use with computer devices

Previous research Increasing PAI teachers using powerpoints in learning through supervising academic practice techniques at SMAN 2 Sigli by Suhardi, Saiful Sagala, Zainuddin explained that this study aimed to find out the improvement in Islamic Religious Education teachers' ability to make learning media using PowerPoint on Islamic development material in the Middle Ages (Middle Ages) 1250-1800) through the technical supervision of engineering workshops at SMAN 2 Sigli.

The subjects in this study were the teachers of Islamic Religious Education at SMAN 2 Sigli with a total of five people. The research design used was a school action research which was carried out in an integrated and systematic manner in stages in the form of cycles. In the first cycle the average ability of teachers in making learning media using powerpoints was $78.21 \%$ with enough categories. In the second cycle the average ability of teachers to make learning media using powerpoints was $88.93 \%$ with a good category. Increasing the average value of teachers in making learning media using powerpoint is $88.93 \%-78.21 \%=10.72 \%$. Thus the results of this study indicate that the application of workshop engineering academic supervision can improve the ability of Islamic Religious Education teachers to make learning media using powerpoints at SMAN 2 Sigli. According to Muammar and Suhartina in a journal entitled Information Technology-based Learning Media in Improving Student Interest (http://ejurnal.iaianpare.ac.id/index.php/kuriositas)Edidah Aqidah Education has an important role in shaping student behavior, because with Aqeedah Moral education, students are not only directed to the achievement of happiness in life in the world, but also to the happiness of living in the afterlife. With Aqeedah moral education students are directed to achieve a balance between outward and inner progress, the balance of relationships between humans in social life and their environment, as well as human relations with their Lord. In addition, it is expected that with the education of Aqidah Akhlak, students will have higher degrees that exceed other creatures. Based on observations and results of interviews with Aqidah Akhlak subject teachers at MTs DDI Pacongang Pinrang, the Aqeedah Akhlak material is often delivered expositoryly. The teacher is considered the only learning resource. This causes students to be less interested and less active in learning. Besides, students seem to be bored with the Aqeedah Moral learning model that has been applied so far. Student involvement is still lacking. The daily scores of the Aqeedah Akhlak subjects are 6.5 class (KKM 7.5) so that 
they have not yet reached the mastery of learning. Student learning outcomes for grade VII MTs DDI Pacongang Pinrang on the average semester report card grades of the 2016-2017 school year is an average of 6.5. Whereas the standard value of students must reach 7.. This is due to the lack of (understanding) student activities in applying the Aqeedah Morals at school or at home or community. Assisted by presenting the media as an intermediary. The complexity of the material that will be conveyed to students can be simplified with the help of media. Media is used as aids in teaching, where the aids in learning include all tools that can be used to help students learn so that they can make it more effective and efficient.

\section{Research Methods}

The research method used is the research and development method. The product development procedure is carried out in stages: (1) potential and problems, (2) data collection, (3) product design, (4) validation, (5) product trials and (6) product revisions.

\section{Discussion}

Final product development is carried out after going through various stages of improvement. Starting from the analysis or initial study stage by means of observation, interviews, and analysis. Analysis of teacher and student needs for students. Then formed the initial product that researchers developed.

The initial product was validated by two experts, namely material expert and media expert. Expert validation was conducted to determine the feasibility of powerpoint-based learning media products in the aqeedah moral learning of V11 Madrasah Tsanawiyah class. Revisions are made after going through that stage. Then enter the trial phase, namely individual, group, and field trials. The purpose of conducting the trial is to determine the feasibility of the product. Revisions made to improvements. So in the end the final product of learning media is formed, that is powerpoint-based learning media.

Material expert assessment of powerpoint development products for the learning of Islamic Morals in class VIII at the madrasah level of tsanawiyah obtained an average score of 83.33 and was in the very valid category.

The assessment of media experts on powerpoint development products for the learning of Islamic Moral in grade VIII at the madrasah level of tsanawiyah was obtained an average score of 75 and was in the valid category.

The feasibility test of the learning media on powerpoint-based moral aqeedah learning was assessed based on the results of the assessment questionnaire score given by the experts, namely the material experts and the media experts produced the following scores: (1) the material experts gave an assessment score of $83.33 \%$, (2) media experts give a score of $75 \%$. After summing and averaging, it produces a score so it can be seen that the average score of cumulative percentage is 79.16 the results of expert feasibility test on powerpoint development products for learning the Morals in the VIII grade of madrasas tsanawiyah is in the valid category. therefore, its eligibility is valid.

Practicality of powerpoint development products for the learning of Islamic Morals in class VIII at the madrasah level of tsanawiyah is done by asking students to be prepared individually, in small groups and in field test groups. Individual practicality testing is done by requesting the willingness of 3 students as a test subject. The results of individual practicality assessment of the product of powerpoint development for learning the moral code in class VIII at the madrasah level in tsanawiyah. 
The results of the individual student test of learning media on learning aqeedah morality based on powerpoint assessment of practical practicality on the product of powerpoint development for morality learning in grade VIII of the tsanawiyah madrasah level obtained an average score of 80.83 and are in the very practical category.

Small group practicality testing is done by asking for the willingness of 8 students as a test subject The results of small group practicality assessment of powerpoint development products for moral learning in the eighth grade madrasah tsanawiyah madrasah level assessment of practical group assessment of the product of powerpoint development for learning the Akidah Akhlak in class VIII Madrasah Tsanawiyah level obtained in the madrasah level of tsanawiyah. the average score is 79.38 and is in the practical category.

The results of the assessment of the practicality of the field groups on the product development of powerpoints for the learning of the Morals in class VIII at the madrasah level of tsanawiyah. Field group practicality assessment of powerpoint development products for the learning of the Morals in the VIII grade of tsanawiyah madrasas obtained an average score of 89.75 and is in the very practical category. And the average N-Gain score is 0.51 thus the resulting media is valid, gets an effective category interpretation so that it can be concluded that the development of powerpoint products with effective categories to improve student learning outcomes.

The effectiveness of learning media on powerpoint-based moral aqeedah learning is obtained through individual, group, and field trials. All three trials have been completed and scores have been obtained from all three. Individual trials ( 3 students) resulted in a value of $80.83 \%$ with a decent product category. While the results of group trials of as many as (8 students) amounted to $89.75 \%$ with a very Eligible category and the results of field trials resulted in a product value of $77.14 \%$ which was included in the effective category. The average evaluation of the results of the above trials shows that the average calculation in the three trials conducted on the product resulted in a value of $83.32 \%$. It can be concluded that in terms of effectiveness, the use of powerpoint-based learning media in the learning of effective aqeedah moral category.

\section{Conclusion}

Development of power point-based learning media on the learning of Aqeedah Akhlak in MTsN Kisaran is done first in conducting a needs analysis and then proceed with the design of powerpoint media. Products are produced as learning media that are used to facilitate students to learn. The feasibility of power point-based learning media on learning Aqeedah Morals in MTsN Kisaran was conducted by material experts with a score of 83.33, a very valid category and a media expert with a score of 75.00 a valid category, so that the cumulative score was 79.16 with a valid category.

Practicality of power point-based learning media in learning Aqeedah Morals in MTsN Kisaran is done by conducting individual trials with a score of 80.83 very practical categories, small group trials with a score of 79.38 practical categories, and field group trials with a score of 89.75 very practical, so that when accumulated a score of 83.33 is obtained with a very practical category.

Effectiveness of powerpoint-based learning media on learning Aqeedah Morals in MTsN Kisaran in improving student learning outcomes obtained an N-Gain score of 0.51 with an effective category so that it can be concluded that the product of powerpoint development for the learning of Morals in the VIII grade of madrasah tsanawiyah level is effective for increasing achievement of the results student learning. 
Suggestions that can be delivered are this product is not the only learning media that can be used as a source of learning. It is therefore recommended to users in addition to using this product also utilize a variety of other learning resources so that they complement each other. To develop the same product in other subjects it is recommended to other developers to make adjustments in the learning design with an analysis of the needs needed, characteristics and context appropriately. Because each subject matter, the characteristics of students and the analysis of needs that surround them are certainly different.Madrasah principals are advised to intervene specifically related to the desire to give birth to learning material products that are in accordance with the characteristics of the institution, the characteristics of students and the context of the environment by providing stimuli including stimulus for teacher accessibility to improve the ability to design learning

\section{References}

Arief S Sadiman et al. (2012). Media Pendidikan Pengertian, Pengembangan, dan Pemanfaatannya, Jakarta: Raja Grafindo Persada.

Benny A. Pribadi. (2017). Media dan Teknologi Dalam Pembelajaran, Jakarta: Kencana.

Dewi, N.R., et al. (2019). Moodle Cloudas the Developing Listening E-Learning Media in SMP Negeri 7 Medan. Britain International of Linguistics, Arts and Education (BIoLAE) Journal, 272-277.

Harahap, H.J.P. and Aini, I. (2019). Development of "Deutsch Für Touristmus" Teaching Based on Livejournal Website toImprove Student Competence inTourism. Britain International of Linguistics, Arts and Education (BIoLAE) Journal, 135-141.

Irfan, Muhiddin and Evi. (2019). Pengembangan Media Pembelajaran Berbasis Powerpoint Pada Mata Pelajaran Ilmu Pengetahuan Alam (IPA) Konsep Alat Pernafasan Pada Manusia Dan Hewan Kelas V SD Negeri Gaddong 1 Makassar. Prosiding Vol.1, ISSN 2715-4866.

Lubis, M. A. (2019). Relationship between Academic Qualification and Madrasah Accreditation with Community Interests in Madrasah Tsanawiyah Private Vocational School, Pematangsiantar City. Britain International of Linguistics, Arts and Education (BIoLAE) Journal, 16-23.

Rusydi Ananda. (2019). Desain Pembelajaran. Medan: LPPPI.

Suhardi, Saiful Sagala, and Zainuddin. (2015). Peningkatan Kemampuan Guru PAI Menggunakan Powerpoint Dalam Pembelajaran Melalui Supervisi Akedemik Teknik Workshop di SMAN 2 Sigli (Jurnal Pendidikan dan Kepengawasan, Vol 2 No. 2, Oktober 2015).

Yunahar Ilyas. (2004). Kuliah Aqidah Islam. Yogyakarta: LPPI. 